\title{
Pengaruh Kualitas Pelayanan Terhadap Kepuasan Pasien Rawat Inap Pada Rumah Sakit Kusta Kediri
}

\author{
Ferry Rizki W; Sudjiono; Mohammad Arifin \\ Fakultas Ekonomi - Universitas Kadiri \\ E-mail : sudjiono@unik-kediri.ac.id
}

\begin{abstract}
This study aims to determine the effect of service quality on inpatient satisfaction at Kediri Leprosy Hospital. The population used was inpatient patients at the Leprosy Hospital and the sample used was 100 people. The results obtained by multiple linear regression equation $\mathrm{Y}=2.046+0.364 \mathrm{X} 1+0.387 \mathrm{X} 2-0.571 \mathrm{X} 3+0.754 \mathrm{X} 4+0.161 \mathrm{X} 5$ can be stated reliability variable (X1), responsiveness (X2), manifestation (X4), empathy (X5) have a positive effect to the satisfaction of inpatients at the Kediri Leprosy Hospital. While the confidence variable (X3) has a negative influence on patient satisfaction. The coefficient of determination (R2) obtained a value of 0.789 . This means that $78.9 \%$ of the dependent variable (patient satisfaction) can be explained by its independent variables (dimensions of reliability, responsiveness, conviction, manifestation and empathy). The remaining $21.1 \%$ is influenced by other variables not included in this research model.
\end{abstract}

Keywords: Physical Evidence, Reliability, Response, Guarantee, Empathy, and Patient Satisfaction

\begin{abstract}
ABSTRAK
Penelitian ini bertujuan untuk mengetahui pengaruh kualitas pelayanan terhadap kepuasan pasien rawat inap pada Rumah Sakit Kusta Kediri. Populasi yang digunakan adalah pasien pasien rawat inap pada Rumah Sakit Kusta dan sampel yang digunakan sebanyak 100 orang. Hasil penelitian diperoleh persamaan regresi linier berganda $\mathrm{Y}=$ $2,046+0,364 X_{1}+0,387 X_{2}-0,571 X_{3}+0,754 X_{4}+0,161 X_{5}$ dapat dinyatakan variabel keandalan $\left(\mathrm{X}_{1}\right)$, ketanggapan $\left(\mathrm{X}_{2}\right)$, keberwujudan $\left(\mathrm{X}_{4}\right)$, empati $\left(\mathrm{X}_{5}\right)$ memberikan pengaruh positif terhadap kepuasan pasien rawat inap pada Rumah Sakit Kusta Kediri. Sedangkan variabel keyakinan $\left(\mathrm{X}_{3}\right)$ memberikan pengaruh negatif terhadap kepuasan pasien. Koefisien determinasi ( $\left.R^{2}\right)$ diperoleh nilai sebesar 0,789. Ini artinya bahwa $78,9 \%$ variabel dependen (kepuasan pasien) dapat dijelaskan oleh variabel independennya (dimensi keandalan, ketanggapan, keyakinan, keberwujudan dan empati). Sisanya sebesar $21,1 \%$ dipengaruhi oleh variabel lain yang tidak diikutsertakan dalam model penelitian ini.
\end{abstract}

Kata Kunci: Bukti Fisik, Kehandalan, Daya Tanggap, Jaminan, Empati, dan Kepuasan Pasien

\section{PENDAHULUAN}

Dewasa ini masalah kesehatan telah menjadi kebutuhan pokok bagi masyarakat. Dengan meningkatnya taraf hidup masyarakat, maka semakin meningkat pula tuntutan 
masyarakat akan kualitas kesehatan. Hal ini menuntut penyedia jasa pelayanan kesehatan seperti rumah sakit untuk meningkatkan kualitas pelayanan yang lebih baik (Yunanto, 2017), tidak hanya pelayanan yang bersifat penyembuhan penyakit tetapi juga mencakup pelayanan yang bersifat pencegahan (preventif) untuk meningkatkan kualitas hidup serta memberikan kepuasan bagi konsumen selaku pengguna jasa kesehatan (Anonim, 2004).

Rumah sakit sebagai institusi yang bergerak di bidang pelayanan kasehatan mengalami perubahan, pada awal perkembangannya, rumah sakit adalah lembaga yang berfungsi sosial, tetapi dengan adanya rumah sakit swasta, menjadikan rumah sakit lebih mengacu sebagai suatu industri yang bergerak dalam bidang pelayanan kesehatan dengan melakukan pengelolaan yang berdasar pada manajemen badan usaha. Seiring dengan itu, terjadi persaingan antara sesama rumah sakit baik rumah sakit milik pemerintah maupun rumah sakit milik swasta, semua berlomba-lomba untuk menarik konsumen agar menggunakan jasanya (Gandung Satriyono, 2018).

Dalam menerima dan melayani pasien rawat inap sebagai konsumen dengan berbagai karakteristik, rumah sakit harus melengkapi diri supaya senantiasa mendengarkan suara konsumen, dan memiliki kemampuan memberikan respon terhadap setiap keinginan, harapan konsumen dan tuntutan pengguna jasa sarana pelayanan kesehatan. Hal ini erat berhubungan dengan tenaga kesehatan yang senantiasa mendampingi dan melayani pasien sebagai konsumennya.

Hal tersebut di atas sejalan dengan pendapat yang dikemukakan Waworuntu (1997:19) bahwa "Seseorang yang profesional dalam dunia administrasi negara menguasai kebutuhan masyarakat dan mengetahui cara memuaskan dan memenuhi kebutuhan masyarakat. Masyarakat perlu dipuaskan melalui pemenuhan kebutuhannya. Sehingga masyarakat merasa sebagai seorang raja, maka harus dilayani dengan baik".

Faktor manusia sebagai pemberi pelayanan terhadap publik dalam organisasi dianggap sangat menentukan dalam menghasilkan pelayanan yang berkualitas. Menurut Thoha (2002:181) "kualitas pelayanan kepada masyarakat sangat tergantung pada individual aktor dan sistem yang dipakai". Dokter, perawat, dan tenaga penunjang medis serta nonmedis yang bertugas di rumah sakit harus memahami cara melayani konsumennya dengan baik terutama kepada pasien dan keluarga pasien, karena pasien dan keluarga pasien adalah konsumen utama di rumah sakit. Kemampuan rumah sakit dalam memenuhi kebutuhan pasien dapat diukur dari tingkat kepuasan pasien.

Pada umumnya pasien yang merasa tidak puas akan mengajukan komplain pada pihak rumah sakit. Komplain yang tidak segera ditangani akan mengakibatkan 
menurunnya kepuasan pasien terhadap kapabilitas pelayanan kesehatan di rumah sakit tersebut. Kepuasan konsumen telah menjadi konsep sentral dalam wacana bisnis dan manajemen. Konsumen umumnya mengharapkan produk berupa barang atau jasa yang dikonsumsi dapat diterima dan dinikmatinya dengan pelayanan yang baik atau memuaskan (Assauri, 2003: 28).

Pasien akan merasa puas apabila ada persamaan antara harapan dan kenyataan pelayanan kesehatan yang diperoleh. Kepuasaan pengguna pelayanan kesehatan mempunyai kaitan yang erat dengan hasil pelayanan kesehatan, baik secara medis maupun non medis seperti kepatuhan terhadap pengobatan, pemahaman terhadap informasi medis dan kelangsungan perawatan (Kotler, 1997: 82).

Berdasarkan hasil pengamatan peneliti memperoleh data jumlah pasien yang pernah dirawat di Rumah Sakit Kusta Kediri selama peride semester I tahun 2017.

Tabel 1 : Jumlah Pasien RS Kusta Kediri Periode semester I Tahun 2017.

\begin{tabular}{|c|r|r|r|r|r|r|}
\hline Keterangan & \multicolumn{1}{|c|}{ Januari } & \multicolumn{1}{c|}{ Februari } & Maret & \multicolumn{1}{c|}{ April } & \multicolumn{1}{c|}{ Mei } & \multicolumn{1}{c|}{ Juni } \\
\hline Rawat Inap & 36 & 44 & 46 & 22 & 31 & 24 \\
\hline Rawat Jalan & 1480 & 1455 & 1491 & 1345 & 1362 & 1059 \\
\hline Jumlah & 1516 & 1499 & 1537 & 1367 & 1393 & 1083 \\
\hline
\end{tabular}

Sumber: RS Kusta Kediri, (2017).

Berdasarkan data kunjungan pasien dan penerimaan rata-rata per bulan pada bulan Januari sampai Juni tahun 2017, terjadi penurunan kira-kira 3-5\% di Rumah Sakit Kusta Kediri. Hal ini mengindikasikan terjadi penurunan kualitas pelayanan di Rumah Sakit Kusta Kediri. Dari uraian di atas sangatlah perlu dilakukan penelitian tentang sejauhmana tingkat kepuasan pasien rawat jalan terhadap pelayanan Rumah Sakit Kusta Kediri yang diharapkan dapat meningkatkan kinerja pelayanan kesehatan.

Adapun yang menjadi tujuan dalam penelitian ini adalah:

1. Untuk mengetahui tingkat kesesuaian antara harapan pasien rawat inap terhadap kualitas pelayanan kesehatan di Rumah Sakit Kusta Kediri.

2. Untuk mengetahui pengaruh kualitas pelayanan terhadap kepuasan pasien rawat inap di Rumah Sakit Kusta Kediri.

\section{TINJAUAN PUSTAKA}

\section{Kualitas Pelayanan Kesehatan}

Kualitas layanan merupakan pelayanan terbaik yang dilakukan oleh seseorang, kelompok atau lembaga yang memberi kepuasan bagi pelanggan atau masyarakat dan pada gilirannya kepuasan itu akan menciptakan loyalitas pelanggan atau masyarakat 
kepada seseorang/ kelompok/lembaga yang memberikan pelayanan tersebut. Pelayanan kesehatan sebagai spesifikasi dari pelayanan publik itu sendiri menurut Levey dan Loomba (dalam Azwar, 1996 : 35) adalah : "Setiap upaya yang diselenggarakan secara sendiri atau secara bersama-sama dalam suatu organisasi untuk memelihara dan meningkatkan kesehatan, mencegah, menyembuhkan penyakit dan memulihkan kesehatan perseorangan, keluarga, kelompok, dan atau pun masyarakat"

Untuk melihat pelayanan itu berkualitas dan memenuhi keinginan pelanggan atau masyarakat, ada beberapa cara-cara untuk menilainya, antara lain dengan sistem keluhan dan saran, survei kepuasan pelanggan, serta pengamatan pada kepuasan pelanggan. Dengan demikian fokus pada kebutuhan/keinginan masyarakat diartikan sebagai orientasi pemerintah terhadap kebutuhan dan keinginan masyarakat atas layanan yang diinginkan masyarakat.

Yang dimaksud dengan kualitas pelayanan kesehatan adalah yang menunjuk pada tingkat kesempurnaan pelayanan kesehatan, yang disatu pihak dapat menimbulkan kepuasan pada setiap pasien sesuai dengan tingkat kepuasan rata-rata penduduk, serta di pihak lain tata cara penyelenggaraannya sesuai dengan kode etik dan standar pelayanan profesi yang telah ditetapkan. Bagi pemakai jasa pelayanan kesehatan (health consumer) dimensi kualitas layanan kesehatan menurut Azwar (1996: 40) sebagai berikut: "Kualitas pelayanan kesehatan lebih terkait pada ketanggapan petugas memenuhi kebutuhan pasien, kelancaran berkomunikasi antara petugas dengan pasien, keprihatinan serta keramahtamahan petugas dalam melayani pasien dan atau kesembuhan penyakit yang sedang diderita oleh pasien”. Petugas dimaksud adalah tenaga medis/dokter dan paramedis serta tenaga pendukung yang bertugas memberikan pelayanan kepada pasien yang dirawat harus mengikuti kode etik yang telah ada.

Kualitas pelayanan kesehatan yang diberikan oleh birokrasi akan dipengaruhi oleh berbagai faktor, seperti tingkat kompetensi aparat, kualitas peralatan yang dipergunakan untuk memproses pelayanan, budaya birokrasi, dan sebagainya. Kompetensi aparat birokrasi merupakan akumulasi dari sejumlah subvariabel seperti tingkat pendidikan, jumlah tahun pengalaman kerja, dan variasi pelatihan yang telah diterima. Kuantitas peralatan yang digunakan akan mempengaruhi prosedur, kecepatan proses, dan kualitas keluaran (output) yang akan dihasilkan. Apabila organisasi menggunakan teknologi modern seperti komputer maka metode dan prosedur kerja akan berbeda dengan ketika organisasi menggunakan cara kerja manual. Dengan mengadopsi teknologi modern dapat menghasilkan output yang lebih banyak dan berkualitas dalam waktu yang relatif cepat. 
Kualitas pelayanan rumah sakit adalah produk akhir dari interaksi dan ketergantungan yang rumit antara berbagai komponen atau aspek rumah sakit sebagai suatu sistem. Kualitas asuhan kesehatan adalah derajat dipenuhinya standar profesi yang baik dalam pelayanan pasien dan terwujudnya hasil akhir seperti yang diharapkan yang menyangkut asuhan, diagnosa, tindakan, dan pemecahan masalah teknis. Pemahaman konsep tentang kualitas pelayanan terikat dengan faktor kepuasan pasien walaupun puasnya pasien itu tidak selalu sama dengan pelayanan berkualitas (Sumarwanto, 1994:54). Umumnya kualitas pelayanan medis di rumah sakit sangat tergantung pada individu dokter, dan diluar kewenangan direksi rumah sakit untuk mengaturnya (Rijanto, 1994:18). Variabel input dalam proses mewujudkan kualitas pelayanan kesehatan adalah :

a. Faktor manusia: pemberi jasa layanan langsung (administrator dan profesional tidak langsung (pemilik ).

b. Faktor sarana: bangunan dan peralatan rumah sakit

c. Faktor manajemen: prosedur pelayanan yang dipergunakan rumah sakit.

Dengan demikian kualitas pelayanan kesehatan yang baik pada dasarnya apabila pelayanan tersebut tersedia dan terjangkau, tepat kebutuhan, tepat tujuan, tepat sumber dayanya, tepat standart profesi, wajar dan aman, memuaskan bagi pasien yang dilayani.

\section{Kepuasan Sebagai Indikator Kualitas Pelayanan}

Menurut Oliver (dalam Barnes, 2003: 64) "kepuasan adalah tanggapan pelanggan atas terpenuhinya kebutuhan", sedangkan Kotler (2000: 36) mengemukakan bahwa tingkat kepuasan adalah: "Satisfaction is a person's feelings of pleasure or disappointment resulting from comparing a product's percieved performance (or outcome) in relation to his or her expectations." Artinya, kepuasan adalah perasaan senang atau kecewa seseorang yang muncul setelah membandingkan antara persepsi/kesannya terhadap kinerja (atau hasil) suatu produk dan harapan-harapannya. Sukar untuk mengukur tingkat kepuasan pasien, karena menyangkut perilaku yang sifatnya sangat subyektif. Kepuasan seseorang terhadap suatu obyek bervariasi mulai dari tingkat sangat puas, puas, cukup puas, kurang puas, sangat tidak puas.

Dengan pelayanan yang sama untuk kasus yang sama bisa terjadi tingkat kepuasan yang dirasakan pasien akan berbeda-beda. Hal ini tergantung dari latar belakang pasien itu sendiri, karakteristik individu yang sudah ada sebelum timbulnya penyakit yang disebut dengan predisposing factor. Faktor-faktor tersebut antara lain : pangkat, tingkat ekonomi, kedudukan sosial, pendidikan, latar belakang sosial budaya, 
sifat umum kesukuan, jenis kelamin, sikap mental dan kepribadian seseorang (Anderson, 2009: 165).

Kepuasan masyarakat sebagai penerima layanan merupakan perbandingan antara layanan yang diterima dengan layanan yang diharapkan. Bila hasilnya mendekati satu maka masyarakat akan puas, begitu juga sebaliknya bila harganya jauh lebih kecil dari satu maka masyarakat semakin tidak puas. Idealnya adalah melebihi satu yang berarti bahwa jasa layanan yang diberikan melebihi harapan, atau ada harapan yang tidak diduga (antisipasi) yang dipuaskan. Bila hal ini tercapai maka masyarakat akan sangat puas terhadap layanan yang diterima Secara teoritis, definisi di atas dapatlah diartikan, bahwa semakin tinggi selisih antara kebutuhan pelayanan kesehatan yang berkualitas sesuai keinginan pasien dengan pelayanan yang telah diterimanya, maka akan terjadi rasa ketidakpuasan pasien. Asumsi teoritis di atas selaras pendapat Gibson (2007:112), yang dapat disimpulkan bahwa kepuasan seseorang (pekerja, pasien atau pelanggan) berarti terpenuhinya kebutuhan yang diinginkan yang diperoleh dari pengalaman melakukan sesuatu, pekerjaan, dan memperoleh perlakuan tertentu atau memperoleh sesuatu sesuai kebutuhan yang diinginkan.

Penilaian terhadap kualitas pelayanan kesehatan sangat penting, sebab dapat digunakan untuk menilai seberapa jauh pelayanan yang diberikan oleh organisasi memenuhi harapan dan memuaskan pengguna jasa. Menurut Dwiyanto (2002: 47) penilaian kualitas pelayanan publik tidak cukup hanya dilakukan dengan menggunakan indikator-indikator yang melekat pada birokrasi/ petugas seperti efisiensi dan efektivitas, tetapi harus dilihat juga dari indikator-indikator yang melekat pada pengguna jasa, seperti kepuasan pengguna jasa, akuntabilitas, dan responsivitas.

Penilaian kualitas dari sisi pengguna jasa menjadi sangat penting karena birokrasi publik seringkali memiliki kewenangan monopolis sehingga para pengguna jasa tidak memiliki alternatif sumber pelayanan. Apabila dicermati berbagai indikator yang dipergunakan untuk mengukur kualitas pelayanan kesehatan sangat bervariasi. Secara umum untuk melihat kualitas pelayanan kesehatan dapat dilihat dari dua perspektif, yaitu perspektif pemberi layanan dan pengguna jasa. Dua pespektif tersebut tidak dapat dilihat secara diametrik, sebab dalam melihat persoalan kualitas pelayanan kesehatan terdapat berbagai faktor yang mempengaruhi secara timbal balik, terutama pengaruh interaksi lingkungan yang dapat mempengaruhi cara pandang pemerintah terhadap masyarakat, atapun sebaliknya.

Kotler (dalam Supranto, 2006 : 231), menjelaskan lima determinan kualitas jasa adalah sebagai berikut: 
a. Keandalan (reliability), yaitu kemampuan untuk melaksanakan jasa yang dijanjikan dengan tepat dan terpercaya.

b. Ketanggapan (responsiveness), yaitu kemauan untuk membantu pelanggan dan memberikan jasa dengan cepat atau ketanggapan.

c. Keyakinan (confidence), yaitu mencakup pengetahuan dan kesopanan karyawan serta kemampuan mereka untuk menimbulkan kepercayaan dan keyakinan atau assurance

d. Empati (emphaty), yaitu syarat untuk peduli, memberi perhatian pribadi bagi pelanggan.

e. Berwujud (tangible), yaitu penampilan fasilitas fisik, peralatan, personil, dan media komunikasi.

\section{Pengukuran Kualitas Pelayanan}

Untuk menganalisa kualitas jasa dapat dilakukan dengan mengkuantifikasikan dimensi kualitas dengan menggunakan skala interval pada kuisioner yang disebarkan kepada responden. Dari hasil skala interval ini, maka kualitas pelayanan dapat diukur. Zeithaml dkk (1988) mengukur kualitas pelayanan dengan perceived service quality, merupakan model yang mengukur perbedaan/gap antara harapan dengan persepsi pelanggan. Hal ini sesuai dengan definisi kualitas pelayanan, yaitu selisih perbedaan antara harapan pelanggan dengan persepsi pelanggan terhadap kinerja jasa yang diterima (Munawaroh, 1999).

Kepuasan pelanggan akan terpenuhi jika apa yang dirasakan melebihi dari apa yang diharapkan. Bila harapan tidak sesuai dengan apa yang dirasakan maka akan menimbulkan gap. Menurut Zeithaml dkk (1990) terdapat lima macam kesenjangan kualitas jasa yang memungkinkan kegagalan penyampaian jasa, yaitu:

1. Gap antara harapan pelanggan dengan persepsi manajemen atas harapan pelanggan.

2. Gap antara persepsi manajemen atas harapan pelanggan dengan spesifikasi kualitas jasa.

3. Gap antara spesifikasi kualitas dengan kualitas jasa yang sebenarnya diberikan.

4. Gap antara jasa yang diberikan dengan jasa yang dikomunikasikan dengan pelanggan.

5. Gap antara harapan pelanggan dan persepsi yang dibentuk dengan apa yang dia rasakan/diterima dari jasa tersebut. 


\section{Hipotesis}

Hipotesis dalam penelitian ini adalah sebagai berikut :

1. Terdapat kesesuaian antara harapan pasien rawat inap terhadap kualitas pelayanan kesehatan di RS Kusta Kediri.

2. Diduga pengaruh yang signifikan kualitas pelayanan terhadap kepuasan pasien pada RS Kusta Kediri

\section{METODE PENELITIAN}

\section{Populasi Dan Sampel Penelitian}

Pada penelitian ini populasinya mencakup seluruh pasien yang menjalankan rawat inap di RS Kusta Kediri dengan sampel penelitian ditentukan sebanyak 100 responden. Sedangkan teknik pengambilan sampel menggunakan teknik purposive sampling, dimana pemilihan sampel berdasarkan atas ciri-ciri/sifat-sifat tertentu yang dipandang mempunyai keterkaitan yang erat dengan ciri-ciri/sifat-sifat populasi yang sudah diketahui sebelumnya (Sutrisno Hadi, 2000: 226). Dimana penulis memberikan kuiseoner kepada setiap individu yang di temui dengan kriteria tertentu. Adapun kriteria yang dipilih sampel antara lain:

1. Responden adalah pasien rawat inap di RS Kusta Kediri lebih dari tiga hari.

2. Responden dipilih yang sedang rawat inap Januari - Juni 2017.

3. Responden hanya mengisi 1 kali (1 kuesieoner)

4. Tidak ada paksaan.

\section{Variabel Penelitian, Cara Pengukuran, dan Definisi Operasional}

Kepuasan konsumen adalah perasaan senang atau kecewa yang dialami konsumen setelah membandingkan antara persepsi kinerja (atau hasil) suatu produk dengan harapan-harapannya. Kualitas pelayanan adalah tingkat keunggulan pelayanan yang dapat memenuhi keinginan konsumen/pelanggan yang diberikan oleh tenaga medis, paramedis, dan penunjang medis. Kualitas pelayanan diukur dengan lima indikator pelayanan (keandalan, ketanggapan, keyakinan, empati, dan berwujud).

a. Keandalan

Keandalan (reliability) merupakan kemampuan rumah sakit untuk menghasilkan produk pelayanan sesuai dengan apa yang dijanjikan. Diantaranya adalah janji ditepati sesuai jadwal dan diagnosisnya terbukti akurat.

b. Ketanggapan

Ketanggapan (responsiveness) merupakan sikap tim medis maupun non medis dalam menanggapi keluhan serta masalah yang dihadapi oleh pasien. Diantaranya 
adalah mudah diakses, tidak lama menunggu, dan bersedia mendengar keluh kesah pasien.

c. Keyakinan

Keyakinan (assurance) adalah pengetahuan yang luas, keramahan, dan kesopanan karyawan yang harus dimiliki oleh para tim medis dan non medis dalam memberikan rasa percaya serta keyakinan kepada para pasien.

d. Empati

Empati (emphaty) adalah kemampuan pihak rumah sakit untuk memberikan perhatian secara individu kepada para pasien. Diantaranya mengenal pasien dengan baik, mengingat masalah (penyakit, keluhan) sebelumnya, dan sabar.

e. Berwujud

Berwujud (tangible) adalah keberadaan fasilitas-fasilitas fisik, peralatan, karyawan, sarana komunikasi dan alat-alat pendukung yang berujud dari rumah sakit dalam memberikan pelayanan kepada para pasien. Diantaranya ruang tunggu, ruang operasi, dan peralatan.

Cara pengukurannya menggunakan kuesioner, skala penilaian menggunakan skala Likert dengan memberikan penilaian atas jawaban untuk kualitas sistem, informasi dan kualitas pelayanan dengan klasifikasi jawaban :

- Sangat Tidak Setuju ( STS ) $=1$

- $\quad$ Tidak Setuju $($ TS $)=2$

- $\operatorname{Netral}(\mathrm{N})=3$.

- Setuju $(\mathrm{S})=4$

- $\quad$ Sangat Setuju ( SS ) $=5$

Untuk mengukur tingkat kepuasan dengan klasifikasi jawaban :

- $\quad$ Sangat Tidak Puas $($ STP $)=1$

- Tidak Puas $(\mathrm{TP})=2$

$-\operatorname{Netral}(\mathrm{N})=3$

$-\operatorname{Puas}(\mathrm{P})=4$

- $\quad$ Sangat Puas $(\mathrm{SP})=5$

\section{Metode Pengumpulan Data.}

1. Data Primer

Data Primer adalah data yang langsung diperoleh dari responden, yaitu berupa jawaban pertanyaan dari kuesioner yang disebarkan tentang variabel kualitas pelayanan $(\mathrm{X})$ dan kepuasan pasien (Y) serta karakteristik/profil responden sebagai data pendukung.

2. Data Sekunder 
Data Sekunder adalah data yang berasal dari sumber-sumber yang berhubungan dengan obyek penelitian yang berupa laporan/catatan perusahaan. Data yang digunakan dalam penelitian ini berupa karakteristik masing-masing pasien rawat inap RS Kusta Kediri.

\section{Metode Analisis Data}

1. Analisis Regresi Linier Berganda

Analisis ini digunakan untuk mengukur pengaruh kualitas pelayanan terhadap kepuasan pasien rawat inap di RS Kusta Kediri. Dengan menggunakan level of significant $(\alpha)$ sebesar 5\%, hasil dari analisis ini dinyatakan dengan persamaan sebagai berikut :

$$
\mathrm{Y}=\mathrm{a}+\mathrm{b}_{1} \mathrm{X}_{1}+\mathrm{b}_{2} \mathrm{X}_{2}+\mathrm{b}_{3} \mathrm{X}_{3}+\mathrm{b}_{4} \mathrm{X}_{4}+\mathrm{b}_{5} \mathrm{X}_{5}+\mathrm{e}
$$

Keterangan :

$\mathrm{Y} \quad=$ Kepuasan pasien rawat inap

$\mathrm{X}_{1}=$ Keandalan

$\mathrm{X}_{2} \quad=$ Ketanggapan

$\mathrm{X}_{3}=$ Keyakinan

$\mathrm{X}_{4} \quad=$ Empati

$\mathrm{X}_{5} \quad=$ Berwujud

$\mathrm{b}_{0} \quad=$ konstanta

b1..b5 = koefisien regresi

e = variabel gangguan (semua variabel yang dihilangkan dari model tetapi secara bersama- sama mempengaruhi Y).

2. Uji F

Digunakan untuk mengetahui apakah variabel bebas secara bersama-sama mempunyai pengaruh yang berarti terhadap variabel terikat. Langkah-langkah pengujian :

a. Ho : $\beta_{1}=\beta_{2}=\beta_{3}=\beta_{4}=\beta_{5}=0$, artinya tidak ada pengaruh yang signifikan secara bersama-sama variabel bebas terhadap variabel terikat.

b. Ha: $\beta_{1} \neq \beta_{2} \neq \beta_{3} \neq \beta_{4} \neq \beta_{5} \neq 0$, artinya ada pengaruh yang signifikan secara bersama-sama variabel bebas terhadap variabel terikat.

Kriteria pengujian

a. $\mathrm{H}_{0}$ diterima bila Fhitung $\leq$ Ftabel

b. $\mathrm{H}_{0}$ ditolak bila $\mathrm{F}_{\text {hitung }}>\mathrm{F}_{\text {tabel }}$

3. Uji t 
Untuk mengetahui diterima atau tidaknya hipotesis yang diajukan, dilakukan analisis secara kuantitatif dengan menggunakan uji t. Uji t ini digunakan untuk menguji keberartian koefisien regresi, dengan menggunakan:

a. Ho : $\beta=0$, artinya tidak ada pengaruh yang signifikan variabel bebas terhadap variabel terikat, secara parsial.

b. Ha : $\beta \neq 0$, artinya ada pengaruh yang signifikan variabel bebas terhadap variabel terikat, secara parsial.

4. Uji Koefisien Determinasi $\left(\mathrm{R}^{2}\right)$

Uji koefisien determinasi ini digunakan untuk mengetahui seberapa besar sumbangan yang diberikan variabel bebas terhadap variabel terikat yang ditunjukan dengan prosentase. Nilai koefisien determinasi adalah $0<\mathrm{R}^{2}<1$. Nilai $\mathrm{R}^{2}$ yang kecil berarti kemampuan variabel independen hampir memberikan semua informasi yang dibutuhkan untuk memprediksi variabel dependen.

\section{HASIL PENELITIAN DAN PEMBAHASAN}

\section{Analisis Gap}

Respon pasien rawat inap terhadap kualitas pelayanan kesehatan di RS Kusta Kediri dimensi keandalan, ketanggapan, keyakinan, keberwujudan dan empati, masingmasing diukur dengan empat butir pertanyaan dengan skala jawaban 1 (Sangat Tidak Setuju - disingkat STS) sampai 5 (Sangat Setuju - disingkat SS).

Tabel 2 : Analisis Gap

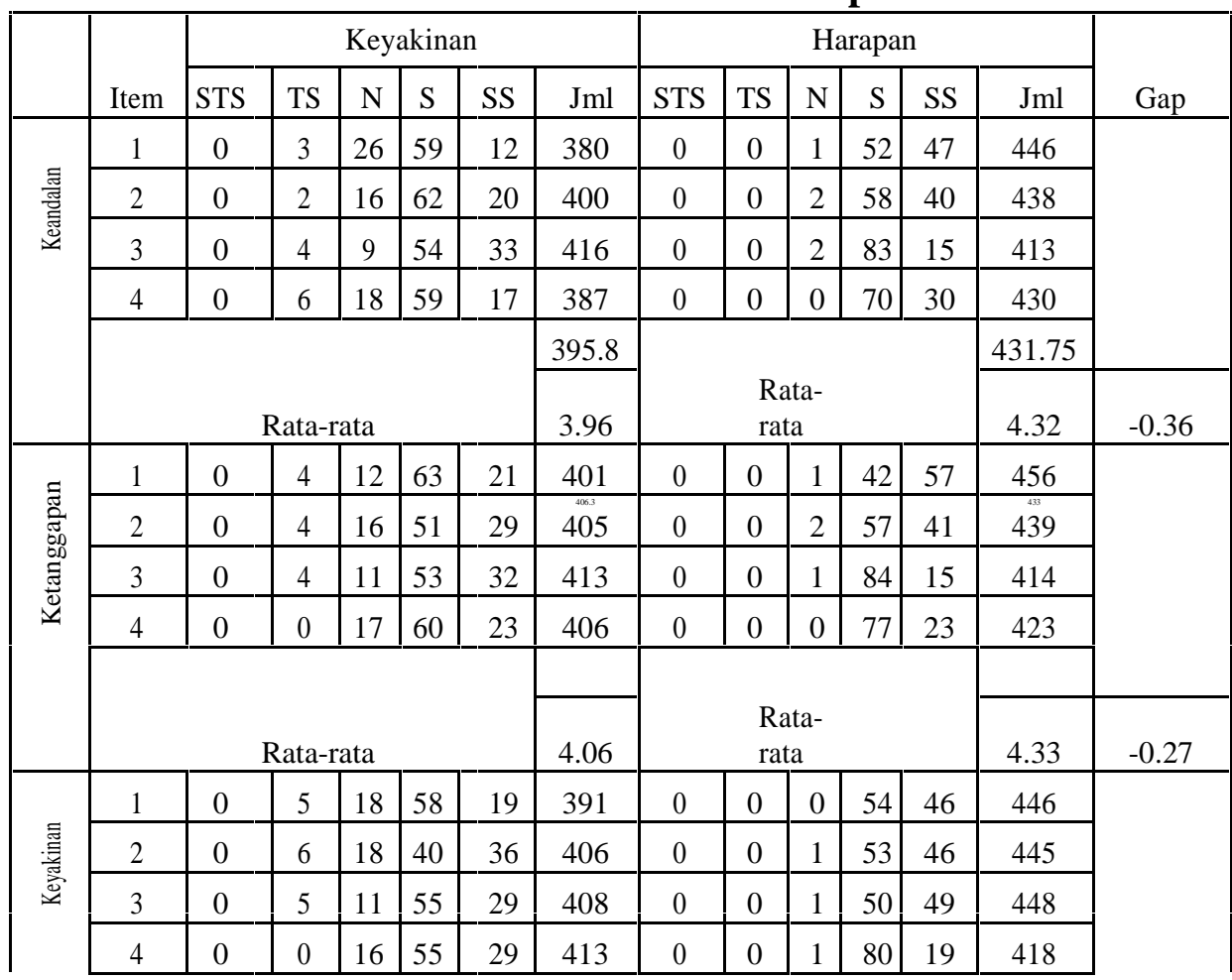




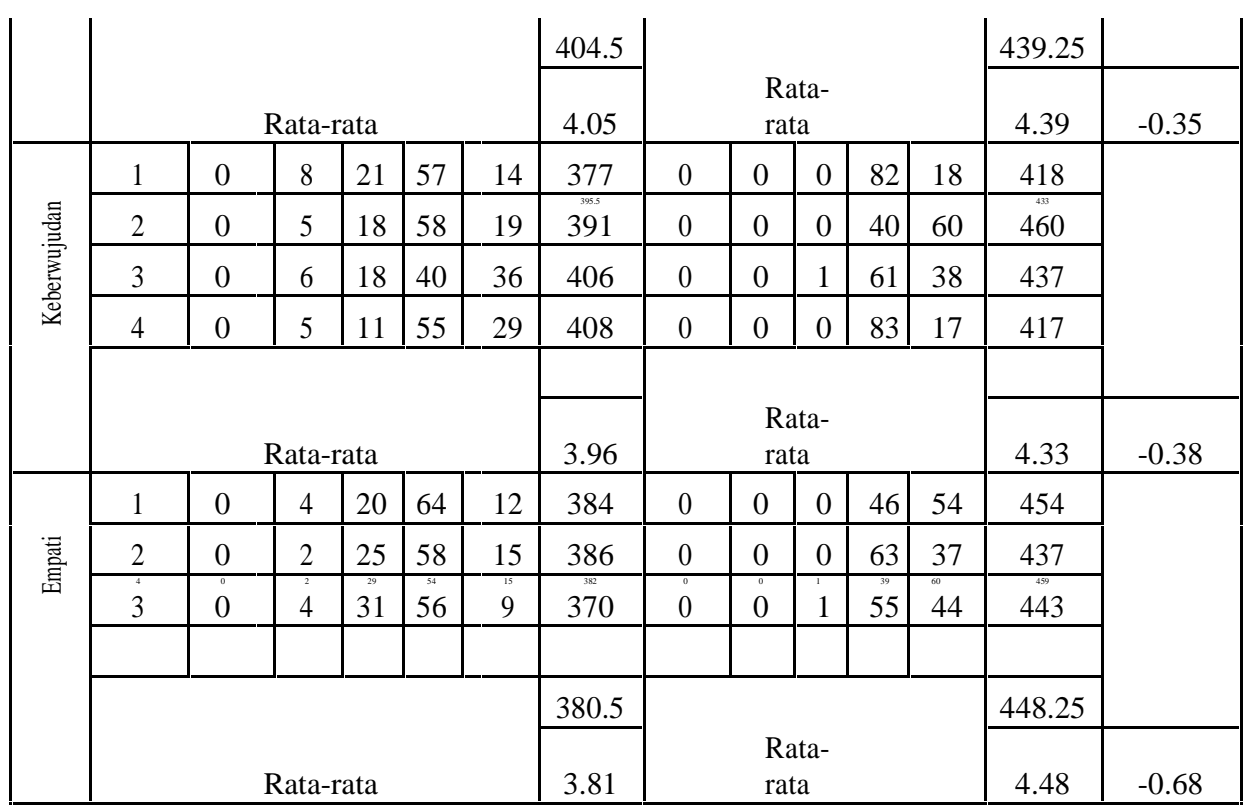

Sumber : Data Primer yang telah Diolah (2017)

Rata-rata respon tersebut kemudian diklasifikasikan agar lebih mudah diinterpretasikan, dalam rentang rata-rata dari terkecil sebesar 1 sampai dengan terbesar sebesar 5 memiliki interval :

Interval $=($ Skor tertinggi - Skor terendah $) /$ Jumlah kelompok

$=(5-1) / 5$

$=0.8($ Sri Mulyono, 1991:9)

Interval

Klasifikasi

$1-1,8$

Sangat rendah

$>1,8-2,6$

Rendah

$>2,6-3,4$

Sedang

$>3,4-4,2$

Tinggi

$>4,2-5$

Sangat tinggi

Dalam tabel 2 terlihat rata-rata dimensi pelayanan pada keyakinan berkisar dari 3,70 sampai dengan 4,16, semuanya termasuk dalam klasifikasi tinggi. Berarti pasien RS Kusta Kediri sudah menilai baik terhadap pelayanan yang ada. Meskipun demikian bila skor keyakinan dibandingkan dengan skor harapan terlihat masih dibawah harapan.

Dalam tabel tersebut terlihat rata-rata pada harapan yang berkisar dari 4,13 sampai 4,60, termasuk dalam klasifikasi sangat tinggi. Selisih (Gap) antara keyakinan dengan harapan menjelaskan tingkat kepuasan pasien, kepuasan paling rendah terjadi pada saat kinerja jauh dibawah harapan, yaitu 
saat kinerja minimal (1) sedangkan harapan maksimal (5), nilainya sebesar 1 $5=-4$. Sebaliknya kepuasan paling tinggi terjadi pada saat kinerja jauh melampaui harapan, yaitu saat kinerja maksimal (5) sedangkan harapan minimal (1), nilainya sebesar $5-1=4$. Rentang kepuasan -4 sampai dengan terbesar sebesar 4 memiliki interval : Interval $=$ (Skor tertinggi - Skor terendah) / Jumlah kelompok

$=(4-(-4)) / 5=1,6($ Sri Mulyono, 1991:9)

Sehingga diperoleh klasifikasi kepuasan :

$\begin{array}{ll}\text { Interval } & \text { Klasifikasi } \\ -4 \text { s/d }-2,4 & \text { Sangat rendah } \\ >-2,4 \text { s/d }-0,8 & \text { Rendah } \\ >-0,8 \text { s/d 0,08 } & \text { Sedang } \\ >0,8 \text { s/d 2,4 } & \text { Tinggi } \\ >\text { 2,4 s/d 4 } & \text { Sangat tinggi }\end{array}$

Dalam tabel 2 terlihat rata-rata kinerja dari semua dimensi pelayanan sebesar 3,97 sedangkan harapannya 4,37, sehingga menghasilkan gap atau tingkat kepuasan sebesar 3,97 - 4,37 =-0,41. Dalam klasifikasi kepuasan gap ini termasuk dalam klasifikasi sedang, berarti pelayanan yang ada di RS Kusta Kediri biasa saja atau moderat.

\section{Pengujian Hipotesis}

1. Tingkat kesesuaian antara harapan pasien rawat inap terhadap kualitas pelayanan kesehatan di RS KUSTA KEDIRI

Uji kepuasan digunakan model indeks kepuasan yang merupakan model pengukuran kepuasan yang digunakan sebagai model dasar dengan menggunakan harapan yang akan datang dan keyakinan yang ada pada RS Kusta Kediri. Skala yang digunakan adalah Skala Likert yaitu skala berjenjang dari nilai 1 sampai dengan 5 dengan pertanyaan tertutup dari tidak setuju sampai sangat setuju, dengan asumsi bahwa setiap orang akan memilih jawaban condong kekiri atau kekanan, hal ini untuk menghindari kecenderungan orang memilih netral.

Analisis deskriptif ini menjelaskan tentang kualitas pelayanan terhadap kepuasan pasien rawat inap, penilaian tingkat kepuasan tersebut didasarkan pada hasil tanggapan responden terhadap tingkat harapan dan keyakinan. Jumlah responden yang diambil berjumlah 100 orang. Setelah dilakukan pembobotan dengan skor yang telah ditentukan, maka dapat ditentukan hasil ratio tingkat kesesuaian kedua data tersebut tentang harapan yang akan datang dengan keyakinan atau kenyataan yang ada di RS Kusta Kediri saat ini. Hasil ini menunjukkan bahwa 
nilai tingkat kepentingan lebih tinggi dari pada nilai kinerja, sehingga menghasilkan nilai rasio kesesuaian sebesar 102,30 \%. Kondisi ini menunjukkan bahwa konsumen merasakan kondisi sangat puas.

Tabel 3 : Kualitas Pelayanan Terhadap Kepuasan Pasien Rawat Inap

\begin{tabular}{|l|c|c|c|c|l|}
\hline \multicolumn{1}{|c|}{ Dimensi } & Keyakinan & Harapan & P $<\mathrm{I}$ & $\mathrm{P}>\mathrm{I}$ & \\
\hline Keandalan & 1583 & 1727 & - & 109.10 & Sangat puas \\
\hline Ketanggapan & 1625 & 1732 & - & 106.58 & Sangat puas \\
\hline Keyakinan & 1618 & 1757 & - & 108.59 & Sangat puas \\
\hline Keberwujudan & 1582 & 1732 & - & 109.48 & Sangat puas \\
\hline Empati & 1522 & 1793 & - & 117.81 & Sangat puas \\
\hline \multicolumn{1}{|c|}{ Total } & 7930 & 8741 & & & \\
\hline
\end{tabular}

Sumber : Data primer yang telah diolah, (2017).

Hasil tersebut menunjukkan bahwa total nilai keyakinan atau kenyataan yang ada lebih rendah dari pada harapan yang akan datang. Dengan hasil tersebut dapat disimpulkan bahwa tanggapan responden terhadap kualitas pelayanan adalah sangat puas.

2. Pengaruh yang signifikan kualitas pelayanan terhadap kepuasan pasien pada RS KUSTA KEDIRI

a. Uji F

Uji $F$ ini bertujuan untuk menguji apakah variabel independen secara bersama-sama mampu mempengaruhi besarnya variabel dependen secara nyata/ signifikan atau tidak. Dari hasil perhitungan dengan menggunakan program bantu SPSS, diketahui besarnya $F=70,155$ sedangkan nilai $F_{\text {tabel }}$ dengan menggunakan $\alpha=0,05$ dan $\mathrm{df}_{1}=5 ; \mathrm{df}_{2}=94\left(\mathrm{~F}_{(0,05 ; 5 ; 94)}\right)$, diperoleh nilai $\mathrm{F}_{\text {tabel }}$ sebesar 2,29. Secara bersama-sama variabel keandalan, ketanggapan, keyakinan, keberwujudan dan empati mempengaruhi kepuasan pasien rawat inap RS Kusta Kediri

Tabel 4 : Hasil Analisis Statistik

\begin{tabular}{|c|c|c|c|}
\hline Variabel & $\mathrm{B}$ & $\mathrm{T}$ & Sig. $\mathrm{t}$ \\
\hline Konstanta & 2,046 & 1,912 & 059 \\
\hline $\mathrm{X} 1$ & ,364 & 4,059 & ,000 \\
\hline $\mathrm{X} 2$ &, 387 & 4,280 & ,000 \\
\hline X3 &,- 571 & $-4,205$ & ,000 \\
\hline $\mathrm{X} 4$ & ,754 & 5,191 & ,000 \\
\hline $\mathrm{X} 5$ & , 161 & 1,989 &, 050 \\
\hline \multicolumn{2}{|l|}{ R. Square } & \multicolumn{2}{|l|}{$=, 789$} \\
\hline \multicolumn{2}{|l|}{$\mathrm{F}$} & \multicolumn{2}{|l|}{$=70,155$} \\
\hline \multicolumn{2}{|l|}{ Sig. F } & \multicolumn{2}{|l|}{$=0,000$} \\
\hline
\end{tabular}

Sumber : Data primer yang telah diolah, (2017). 
b. Uji t

Uji t merupakan uji kecocokan model secara individu variabel kualitas pelayanan yang meliputi dimensi keandalan, ketanggapan, keyakinan, keberwujudan dan empati. Suatu variabel independen berpengaruh terhadap variabel dependen dilihat dari nilai signifikansi uji t. Nilai itu dikatakan signifikan jika tingkat signifikansi $<0,05$.

c. Analisis Regresi Linear Berganda

Berdasarkan hasil perhitungan, maka diperoleh persamaan regresi linear berganda sebagai berikut :

$$
Y=2,046+0,364 X_{1}+0,387 X_{2}-0,571 X_{3}+0,754 X_{4}+0,161 X_{5}
$$

Atas dasar persamaan tersebut, Variabel keandalan $\left(\mathrm{X}_{1}\right)$, ketanggapan $\left(\mathrm{X}_{2}\right)$, keberwujudan $\left(\mathrm{X}_{4}\right)$, empati $\left(\mathrm{X}_{5}\right)$ berpengaruh positif terhadap kepuasan pasien, sedangkan variabel Keyakinan $\left(\mathrm{X}_{3}\right)$ berpengaruh negatif terhadap kepuasan pasien RS Kusta Kediri.

d. $R$ Square

Dari Tabel 9 dapat dilihat tentang nilai korelasi atau hubungan antara variabel dependen (Y) dengan variabel independen (X).

Nilai secara umum $(\mathrm{R})$ sebesar 0,245 , sedangkan nilai $R$ square yang telah disesuaikan (adjusted $R$ square) sebesar 0,789. Ini artinya bahwa 78,9\% variabel dependen (kepuasan pasien) dapat dijelaskan oleh variabel independennya (dimensi keandalan, ketanggapan, keyakinan, keberwujudan dan empati). Sisanya sebesar $21,1 \%$ dipengaruhi oleh variabel lain yang tidak diikutsertakan dalam model penelitian ini.

\section{KESIMPULAN DAN SARAN}

\section{Kesimpulan}

Berdasarkan hasil penelitian dan pembahasan, maka ada beberapa kesimpulan, sebagai berikut :

1. Berdasarkan analisis gap dimensi pelayanan secara keseluruhan, kesesuaian antara pelayanan yang diberikan oleh RS Kusta Kediri dengan harapan pasien terdapat gap/ tingkat kepuasan sebesar $(-0,36)$, skor ini dikategorikan dalam kelompok sedang, meskipun belum sepenuhnya memenuhi harapan pasien tetapi pelayanan yang diberikan sudah cukup baik. 
2. Berdasarkan hasil analisis regresi diatas dapat disimpulkan bahwa semua variabel dari dimensi kualitas pelayanan (keandalan, ketanggapan, keyakinan, keberwujudan dan empati) secara bersama-sama memiliki pengaruh positif dan signifikan terhadap kepuasan pasien rawat inap RS Kusta Kediri.

3. Hasil uji hipotesis alternatif (Ha) dapat diterima dan hipotesis nihil (Ho) ditolak, pengaruhnya yang paling besar adalah variabel keberwujudan $(5,191)$ diikuti ketanggapan (4,280), keandalan (4,059), empati (1.989), dan keyakinan $(-4,205)$ terhadap kepuasan pasien rawat inap RS Kusta Kediri.

4. Variabel yang paling memuaskan pasien yaitu variabel yang memiliki tingkat kepuasan terbesar atau gap paling kecil yaitu variabel empati, kemudian variabel selanjutnya diikuti variabel keberwujudan, variabel keandalan, variabel keyakinan, dan yang terakhir variabel ketanggapan.

5. Meskipun belum sepenuhnya pelayanan yang diberikan sesuai harapan, tetapi pelayanan RS Kusta Kediri sudah cukup baik dan agar terus ditingkatkan.

\section{Saran}

Berikut adalah beberapa saran yang bisa diberikan oleh peneliti :

1. Untuk meningkatkan kualitas layanan agar lebih mempertahankan tingkat layanan yang memuaskan, pihak RS Kusta Kediri sebaiknya tetap mempertahankan kondisi seperti pada dimensi empati.

2. Item-item yang masih kurang pelayanannya atau yang mempunyai gap paling besar di masing-masing dimensi kualitas agar selalu diperhatikan dan ditingkatkan pelayanannya agar memuaskan pasien.

3. RS Kusta Kediri perlu secara rutin mengamati pelayanannya agar dapat mempertahankan kelebihan-kelebihan yang ada dan selalu meningkatkan kualitas pelayanan pada variabel-variabel yang masih kurang penilaiannya.

4. RS Kusta Kediri lebih memperhatikan terhadap kebutuhan dan keinginan pasien, peningkatan fasilitas sarana dan prasarana, jaminan rasa aman, nyaman, dan kepercayaan serta pelayanan yang dijanjikan secara cepat, akurat dan pasti sehingga akan meningkatkan kepuasan pasien.

5. RS Kusta Kediri perlu mencari terobosan baru yang dapat meningkatkan kepuasan pasien rawat inap. 


\section{DAFTAR PUSTAKA}

Anderson, R. Joanna K, dkk. 2009. Equity in Health Service, Emperical Analysis in Social Policy. Mass Ballinger Publishing Campany. Cambrige.

Arikunto, S. 199. Prosedur Penelitian Suatu Pendekatan Praktek, Rineka Cipta, Jakarta.

Assauri, S. 2003. Customer Service yang Baik Landasan Pencapaian Customer Satisfaction dalam Usahawan, No. 01, Tahun XXXII, Januari, hal.25-30: Jakarta.

Aviliani dan Wilfidrus, 1997. "Membangun Kepuasan Pelanggan Melalui Kualitas Pelayanan". Usahawan No.05 Tahun XXVI, Mei.

Azwar,S. 1996. Reliabilitas dan Validitas. Edisi ketiga. Pustaka Pelajar, Yogyakarta.

Azwar, Azrul H. 1996. Menjaga Mutu Pelayanan Kesehatan. Jakarta: Pustaka Sinar Harapan.

Azis Slamet Wiyono dan M. Wahyuddin. (2005). Studi Tentang Kualitas Pelayanan dan Kepuasan Konsumen di Rumah Sakit Islam Manisrenggo Klaten, Surakarta: Program Pascasarjana Universitas Muhammadiyah Surakarta.

Budiyanto, FX. 1991. Pelayanan Pelanggan yang Ber,utu, Seni Melakukan Pelanggan Sebagai Tamu. Jakarta: Binarupa Aksara

Djarwanto Ps dan Pangestu Subagyo. 1999. Statistik Induktif. BPFE, Yogyakarta.

Donabedian, A. 2000. Exprolation in Quality Assesment and Monitoring. Arbor Michigan: Health Administration Press.

Dwiyanto, A. 2002. Reformasi Birokrasi Publik di Indonesia. Yogyakarta: Pusat Studi Kependudukan UGM.

Gibson, JL. et.al. 2007. Organisasi dan Manajemen Perilaku, Struktur, Proses. Jakarta: Erlangga

Goldberg, A. 1996. Hospital Departemen Profil. USA: American Hospital Publishing, Co. INC.

Gonzales, 2007. Cultur, Diseas and Healing Studies in Medical Anthropology. New York: Millan Publishing, Co. INC.

Ghozali, I. 2005. Metode Penelitian Bisnis, Bagian Penerbitan FE-UNDIP, Semarang.

Gandung Satriyono, D. K. (2018). Pengaruh Kepuasan Pasien Pada Kualitas Layanan Rawat Inap Terhadap Niat Discharge Against Medical Advice (DAMA) (Studi di Rumah Sakit Umum Daerah Pare Kabupaten Kediri). Ekonika, 3(2), 136-153.

Gujarati, D. 1997. Ekonometrika Dasar, PT. Gelora Aksara, Jakarta

Ibrahim, B. 1997. "TQM, Panduan Untuk Menghadapi Pasar Global" Penerbit Djambatan, Jakarta.

John, J., 1992. Patient Satisfaction: The Impact of Past Exdperience. JHCM. Vol 12. No. 3. pp 56-64.

Jacobalis, S. 1995. Liberalisasi Bisnis Jasa Kesehatan dan Dampaknya Bagi Rumah Sakit Indonesia. Jakarta: IRSJAM XXXVII.

Kotler, P. 2000. Manajemen Pemasaran : Analisis, Perencanaan, Implementasi dan Pengendalian, diindonesiakan oleh Ancella Aniwati Hermawan, Salemba Empat : Prentice Hall Edisi Indonesia.

Rijanto, S. 1994. "Tantangan Industri Rumah Sakit Indonesia tahun 2020”. Jurnal Kajian Administrasi Rumah Sakit. Jakarta: UI Press.

Singarimbun, M.; dan Effendi, S.(eds.). 1997. Metode Penelitian Survei. LP3ES: Jakarta. 
Sugiyono, 2001. Metodologi Penelitian Bisnis, Alfabeta, Bandung.

Sutrisno, H, 1992. Analisis Butir Untuk Instrumen Angket,Tes, dan Skala Nilai dengan BASICA. Edisi Pertama,cetakan pertama. Penerbit Andi Offset, Yogyakarta.

Sumarwanto, E. 1994. "Standar Perilaku Sebagai Upaya Peningkatan Mutu Pelayanan". Cermin Dunia Kedokteran. No. 19. Jakarta.

Supranto, J. 2006. Pengukuran Tingkat Kepuasan Pelanggan untuk Menangkap Pangsa Pasar. Jakarta: Rineka Cipta.

Snook, JR. D. 2001. Hospital What They are and How They Work. Maryland London: An Aspen Publication Rock Ville,

Thoha, M. 2002. Perilaku Organisasi. Jakarta: Raja Grafindo Persada.

Tjiptono, F. 2000. Strategi Pemasaran, Andi Offset, Yogyakarta

Utama, S. 2005. "Memahami Fenomena Kepuasan Pasien Rumah Sakit". Jurnal Manajemen Kesehatan. 09 (1), 1-7.

Waworuntu, B. 1997. Dasar-dasar Keterampilan Abdi Negara Melayani Masyarakat. Jakarta: Gramedia Pustaka Utama.

Yunanto, Y. (2017). Pengaruh Kualitias Peayanan Dan Disiplin Kerja Aryawan Biro Administrasi Umum Terhadap Kepuasan Mahasiswa, 15(2), 99-104.

Zeithaml V.A., A. Parasuraman, and L.L. Berry (1990) "Delivery Quality Service Balancing Costumer Perseptions and Expectation". New York: The Free Press P. 46. 